\title{
The prevalence of factor V 1691G-A mutation in Van region of Turkey
}

\author{
Türkiye'de Van bölgesinde Faktör V 1691G-A mutasyonunun prevalansı
}

\author{
Sinan Akbayram, Cihangir Akgün², Murat Doğan², Mehmet Selçuk Bektaş², \\ Ahmet Faik Öner ${ }^{1}$ \\ 1'Department of Pediatric Hematology, Yüzüncü Yll University Faculty of Medicine, Van, Turkey \\ 2Department of Pediatrics, Yüzüncü Yll University Faculty of Medicine, Van, Turkey
}

\section{To the Editor,}

The prevalence of hereditary thrombotic risk factors shows marked ethnic and geographic variations. Hereditary disorders predisposing for thrombosis are not only antithrombin, protein $\mathrm{C}$ and protein $\mathrm{S}$ deficiencies, but also hereditary defects such as factor V 1691 G-A (Leiden) (FVL) and prothrombin $20210 \mathrm{G}$ - A mutations [1,2]. FVL causes activated protein $\mathrm{C}$ resistance and is the most common thrombophilic mutation worldwide [3]. Guanine to adenine change leads to a replacement of glutamine with arginine at amino acid position 506 . It is most prevalent among Caucasians but not found in the Japanese and Africans [1-3]. FVL frequency in the Turkish population has been reported from different parts of Turkey. Overall frequency was reported to be $8 \%$ [4]. FVL is believed to have originated somewhere close to Anatolia approximately 20,000 years ago, and the existence of mutation in this geography is expected to be high [5]. Urartu, one of the ancient civilizations in Anatolia, was an Iron Age kingdom, centered on Van Lake in Eastern Turkey. In the study of Dogan Alakoc et al. [5], 60 teeth from the excavations of Van
Yoncatepe fortress were subjected to DNA analysis. Of the total60samples, onemale sample demonstrated a positive amplification result for FV gene and was found to be heterozygous for FVL.

As there is no report on the prevalence of FVL in the population in the Van region of Turkey, we aimed to determine the prevalence in that province.

A total of 100 healthy children were studied. The mean age of the 100 subjects was $9.08 \pm 5.94$ years, and 49 (49\%) were males and 51 (51\%) females. A written consent was obtained from their parents. The frequency of FVL was determined as $9 \%$.

FVL frequency is about 3\% to 10\% in Europeans, but the FVL mutation is rare in East and/or Southeast Asian populations; however, it has been determined at high frequencies in Azerbaijan and Kyrgyzstan populations [6-9].

Wide variations in the frequency of FVL have been reported in different surveys carried out in many countries, depending on the geographical location and the ethnic background of the population. In Caucasian populations, the carrier frequency of FVL was reported to be $2-15 \%$ [4]. The highest prevalence rates were obtained in Mediterranean countries [3-7]. 
The rates from different regions of Turkey and our results showed similar frequencies.

The high prevalence of the mutation in the Middle East leads to the possibility that the founders of the FVL mutation lived around this region [10]. Another study on population genetics of the mutation showed that during the Neolithic period, FVL in Europe had probably expanded from Turkey, Anatolia [6]. One more clue to this statement is the presence of FVL in Urartians [5].

In conclusion, according to the results of this study, FVL prevalence is quite high and not rare in the population of the Van region of Turkey.

\section{Acknowledgement}

We are grateful to Nejat Akar and Yonca Eğin (Ankara University, Pediatric Genetics Department) for the analysis of the samples. Informed consent was obtained from the patient.

\section{Conflict of Interest}

No author of this paper has a conflict of interest, including specific financial interests, relationships, and/or affiliations relevant to the subject matter or materials included in this manuscript.

\section{References}

1. Bertina RM, Koeleman BP, Koster T, Rosendaal FR, Dirven RJ, de Ronde $\mathrm{H}$, van der Velden PA, Reitsma
PH. Mutation in blood coagulation factor $\mathrm{V}$ associated with resistance to activated protein C. Nature 1994;369:64-7.

2. Poort SR, Rosendaal FR, Reitsma PH, Bertina RM. A common genetic variation in the 3 '-untranslated region of the prothrombin gene is associated with elevated plasma prothrombin levels and an increase in venous thrombosis. Blood 1996;88:3698-703.

3. Rees DC, Cox M, Clegg JB. World distribution of factor V Leiden. Lancet 1995;346:1133-4.

4. Akar N. Factor V 1691 G-A mutation distribution in a healthy Turkish population. Turk J Hematol 2009;26:9-11.

5. Dogan Alakoc Y, Aka S, Egin Y, Akar N. Factor V Leiden in an Urartian, dating back to 1000 BC. Clin Appl Thromb Hemost 2009 Jul 17. [Epub ahead of print]

6. Lucotte G, Mercier G. Population genetics of factor V Leiden in Europe. Blood Cells Mol Dis 2001;27:362-7.

7. Herrmann FH, Koesling M, Schröder W, Altman R, Jiménez Bonilla R, Lopaciuk S, Perez-Requejo JL, Singh JR. Prevalence of factor V Leiden mutation in various populations. Genet Epidemiol 1997;14:403-11.

8. Gurgey A, Rustemov R, Parlak H, Balta G. Prevalence of factor $\mathrm{V}$ Leiden and methylenetetrahydrofolate reductase C677T mutations in Azerbaijan. Thromb Haemost 1998;80:520-1.

9. Gurgey A, Kudayarov DK, Tuncer M, Parlak H, Altay C. The factor V Leiden and prothrombin G20210A mutations in Kirghiz population. Thromb Haemost 2000;84:356.

10. Akar N, Akar E, Dalgin G, Sözüöz A, Omürlü K, Cin S. Frequency of factor V (1691 G --> A) mutation in Turkish population. Thromb Haemost 1997;78:1527-8. 